\title{
THE WARSAW STOCK EXCHANGE INDEX WIG: MODELLING AND FORECASTING
}

\author{
PIOTR WDOWINSKI \\ ANETA ZGLINSKA-PIETRZAK \\ CESIFO WORKING PAPER NO. 1570 \\ CATEgory 6: MONETARy Policy and InTERnational Finance \\ OCTOBER 2005
}

\footnotetext{
An electronic version of the paper may be downloaded

- from the SSRN website:

www.SSRN.com

- from the CESifo website:

www.CESifo-group.de
} 


\title{
THE WARSAW STOCK EXCHANGE INDEX WIG: MODELLING AND FORECASTING
}

\begin{abstract}
In this paper we have assessed an influence of the NYSE Stock Exchange indexes (DJIA and NASDAQ) and European Stock indexes (DAX and FTSE) on the Warsaw Stock Exchange index WIG within a framework of a GARCH model. By applying a procedure of checking predictive quality of econometric models as proposed by Fair and Shiller (1990), we have found that the NYSE market has relatively more power than European markets in explaining the WSE index WIG.
\end{abstract}

JEL Code: C2, C5, C6, G1.

Keywords: Warsaw Stock Exchange, stock index, GARCH model, forecasting.

\author{
Piotr Wdowinski \\ University of Lodz \\ Institute of Econometrics and Statistics \\ Department of Econometrics \\ Rewolucji 1905 r. No. 41 \\ 90-214 Lodz \\ Poland \\ piotrw@uni.lodz.pl
}

\author{
Aneta Zglinska-Pietrzak \\ University of Lodz \\ Institute of Econometrics and Statistics \\ Department of Econometrics \\ Rewolucji 1905 r. No. 41 \\ 90-214 Lodz \\ Poland \\ pietrzak@uni.lodz.pl
}

We are grateful to our colleagues from the Department of Econometrics, University of Lodz, and participants of annual conference Forecasting Financial Markets and Economic Decision-making (FindEcon 2004) at Department of Econometrics (University of Lodz) for helpful comments and suggestions on earlier draft of the paper. The usual disclaimer applies. 


\section{Introduction}

The problem of searching for the influence of large markets on others has been wellknown from literature for years. However, this kind of relationship has been widely studied through analysing correlations between individual indexes representing different markets (see e.g. Erb et al. 1994; Bracker and Koch 1999).

In this paper we try to find such dependence between WIG index and foreign stock market indexes (DJIA, NASDAQ and DAX, FTSE) by estimating parameters in regressions of WIG.

The estimates show which foreign stock market affects Polish stock exchange index more strongly. We also test it by the forecasting approach using forecast errors of WIG index obtained in individual regressions. We use also the idea of combined forecasts.

There are many methods used to combine forecasts (see e.g. Clemen 1989; Granger 1989). As shown by Clemen and Winkler (1986), simple combination methods often work better than more complex approach. The aim of combining forecasts is to investigate whether the forecast combination plays an important role in the improvement of forecasting accuracy. The well-known way of combining forecasts is to compute linear combination of forecasts generated by alternative models or obtained by using different forecasting methods (see e.g. Billio, Sartore and Toffano 2000; Claessen and Mittnik 2002).

Dependence between stock markets in different countries has been tested for years. Many analyses deal with measuring correlation between returns and diversified international portfolios (see e.g. Grubel 1968; Levy and Sarnat 1970; Agmon 1972; Fiszeder 2003).

In the 1990s there appeared research of how changes to stock prices on one market affect other markets (see e.g. Hamao, Masulis and Ng 1990; King and Wadhwani 1990; Engle and Susmel 1993; Fiszeder 2001).

The focus of this paper is to find the influence of American and European indexes on Warsaw Stock Exchange index WIG. There is a lot of research which prove that this influence does exist. We aim to examine which market - American or European - has a stronger impact on WIG index.

The paper is structured as follows. In Section 1 we give a brief overview of the GARCH methodology. In Section 2 we test for influence of foreign stock indexes on WIG 
index. Combined forecasting of WIG index is applied in Section 3, and finally we give concluding remarks.

\section{The GARCH methodology}

Many models have been proposed to describe volatility of returns. Now there is a comprehensive literature with several specifications of autoregression models. Many empirical analyses, however, have shown that GARCH approach is the most appropriate. We also apply GARCH modelling in this paper. This is the most popular class of models used in modelling the financial time series of high frequency (see e.g. Akgiray 1989; Schwert and Seguin 1990; Nelson 1991; Andersen, Bollerslev and Lange 1999; Osiewalski and Pipien 1999 and 2004; Bollerslev and Wright 2000; Fiszeder 2001 and 2003; Brzeszczynski and Kelm 2002; Doman M. and Doman R. 2003).

The GARCH model has been proposed independently by Bollerslev (1986) and Taylor (1986) as a generalisation of ARCH model introduced by Engle (1982).

The main feature of ARCH model is to describe the conditional variance as an autoregression process. However, most empirical time series require using long-lag length ARCH models and a large number of parameters must be estimated. The solution of the problem was GARCH models which gave better results (see Engle and Bollerslev 1986; Nelson 1991).

The basic linear generalised autoregressive conditional heteroscedastic GARCH(p,q) model is given as follows (see e.g. Bollerslev 1986):

$$
y_{t}=\mathbf{x}_{(\mathbf{k}) \mathbf{t}} \boldsymbol{\alpha}_{(\mathbf{k})}+\varepsilon_{t},
$$

where:

$$
\varepsilon_{t}=\vartheta_{t} \sqrt{h_{t}}
$$

and $h_{t}$ is a function of conditional variance represented as:

$$
h_{t}=\gamma_{0}+\sum_{i=1}^{p} \gamma_{i} \varepsilon_{t-i}^{2}+\sum_{j=1}^{q} \phi_{j} h_{t-j}
$$

where: $\vartheta_{t}$ is i.i.d with $E\left(\vartheta_{t}\right)=0$ and $\operatorname{var}\left(\vartheta_{t}\right)=1, \quad \gamma_{0}>0, \quad \gamma_{i} \geq 0, \quad \phi_{j} \geq 0$. If $\sum_{i=1}^{p} \gamma_{i}+\sum_{j=1}^{q} \phi_{j}<1$, the process $h_{t}$ is covariance stationary. 
Engle and Bollerslev (1986) considered also GARCH processes with $\sum_{i=1}^{p} \gamma_{i}+\sum_{j=1}^{q} \phi_{j}=1$, which they denoted integrated GARCH (IGARCH).

In empirical research the most frequently used is $\operatorname{GARCH}(1,1)$ model in which $h_{t}=\gamma_{0}+\gamma_{1} \varepsilon_{t-1}^{2}+\phi_{1} h_{t-1}$ and $\gamma_{0}>0, \gamma_{1} \geq 0, \phi_{1} \geq 0$. When $\gamma_{1}+\phi_{1}<1$, than unconditional variance of $\varepsilon_{t}$ is given by $\operatorname{var}\left(\varepsilon_{t}\right)=\frac{\gamma_{0}}{1-\gamma_{1}-\phi_{1}}$. The coefficients of the model are then easily interpreted, with the estimate of $\gamma_{1}$ showing the impact of current news on the conditional variance process and the estimate of $\phi_{1}$ as the persistence of volatility to a shock or, alternatively, the impact of „old” news on volatility.

Recently a number of new formulations have been proposed, e.g. exponential GARCH(p,q) model (EGARCH, see e.g. Nelson 1991), GJR-GARCH model (see e.g. Glosten, Jagannathan and Runkle 1993), GARCH in the mean (GARCH-M(p,q), see Engle, Lilien and Robins 1987), power GARCH (PGARCH, see Ding, Granger and Engle 1993), and the fractionally integrated GARCH (FIGARCH, see Baillie et al. 1996).

Such models are commonly applied in financial time series research. The estimation of GARCH models is both classic and non-classic, e.g. Bayesian approach (see e.g. Osiewalski and Pipien 1999 and 2004).

In Section 2 we test models for influence of foreign stock markets on the Polish market.

\section{Testing for influence of foreign stock indexes on WIG index}

In the paper we use a GARCH methodology with $\operatorname{GARCH}(1,1)$ models. We have found that both ARCH and GARCH effects appeared to be statistically significant in the dependence tested.

The focus of the paper is to find the influence of American and European stock market indexes on WIG index over the period 1.01.1995 to 29.12.2003 (2346 observations).

After introducing suggested foreign indexes to the $\operatorname{GARCH}(1,1)$ equation describing WIG index, it was impossible to separate mutual relationships between index WIG and foreign indexes, mainly DAX and FTSE, because the estimates used to be statistically insignificant and had opposite signs which negated the assumptions of positive influence of the biggest stock markets on index WIG. Hence, we were unable to include both European 
indexes DAX and FTSE in one equation, and we decided to test for the influence of European markets by two equations accordingly.

In turn, we analyse the following models:

- $\quad$ for American market:

$$
\operatorname{wig}_{t}=\alpha_{0}+\alpha_{1} \dot{d j i a}{ }_{t-1}+\alpha_{2} \operatorname{nas}_{\dot{d} a q_{t-1}}+\varepsilon_{t} \text {, }
$$

- $\quad$ for European market:

$$
\stackrel{\bullet}{\operatorname{wig}_{t}}=\alpha_{0}+\alpha_{1} \dot{d a x} t-1+\varepsilon_{t}
$$

or

$$
\dot{w i g}_{t}=\alpha_{0}+\alpha_{1} \dot{f t s e}_{t-1}+\varepsilon_{t}
$$

where the variables are first differences of natural logarithms, so they are the close-to-close returns on corresponding indexes.

The estimation was made by maximum likelihood method $^{1}$ for daily data from 1.01.1995 to 29.12.2003.

The equations (4), (5) and (6) were recursively estimated and helped to obtain a series of 250 one-period-ahead quasi ex ante forecasts. The estimates of individual equations were generally statistically significant. The sum $\hat{\gamma}_{1}+\hat{\phi}_{1}$ in the equation of conditional variance was around 0.92, while the estimates $\hat{\gamma}_{1}$ were about 0.12 and $\hat{\phi}_{1}$ about 0.80 . Hence, we can conclude that the impact of current news on volatility in the conditional variance process is smaller than the impact of „old” news.

The coefficient of determination R-squared for corresponding equations (4), (5) and (6) was about $12 \%, 3 \%$ and $3 \%$ respectively.

In Table 1 we give measurement of ex post errors ${ }^{2}$ for forecasts obtained from respective equations of index WIG.

\footnotetext{
${ }^{1}$ We used Econometric Views package.

${ }^{2}$ We used the following ex post errors: MAE - mean absolute error, RMSE - root mean square error, THEIL Theil's inequality coefficient, I1, I2, I3 - decomposition of Theil's inequality coefficient, TP1 and TP2 - turning points test statistics.
} 
Table 1. Ex post errors of index WIG forecasts

\begin{tabular}{|c|c|c|c|}
\hline & DJIA-NASDAQ & DAX & FTSE \\
\hline MAE & 0.00922 & 0.00926 & 0.00929 \\
\hline RMSE & 0.01193 & 0.01197 & 0.01213 \\
\hline THEIL & 0.75195 & 0.82760 & 0.84897 \\
\hline $\mathrm{I}_{1}{ }^{2}$ & 0.005 & 0.004 & 0.005 \\
\hline $\mathrm{I}_{2}{ }^{2}$ & 0.411 & 0.575 & 0.582 \\
\hline $\mathrm{I}_{3}{ }^{2}$ & 0.588 & 0.425 & 0.417 \\
\hline $\mathrm{TP} 1 \%)$ & 19.69 & 13.39 & 15.75 \\
\hline TP2 (\%) & 50.21 & 43.57 & 47.72 \\
\hline
\end{tabular}

Source: own calculations.

In the analysis of ex post errors we used turning points test statistic - TP1- represented as:

$$
T P 1=\frac{N\left(r_{t} r_{t}^{*}>0 \wedge r_{t-1} r_{t-1}^{*}>0 \mid r_{t} r_{t-1}<0\right)}{N\left(r_{t} r_{t-1}<0\right)},
$$

where:

$N\left(r_{t} r_{t-1}<0\right)$ - a number of turning points in empirical series,

$N\left(r_{t} r_{t}^{*}>0 \wedge r_{t-1} r_{t-1}^{*}>0 \mid r_{t} r_{t-1}<0\right)-$ a number of points, in which changes to direction in empirical and forecasting series are the same in the period $t$ and $t-1$ under the condition that the points are turning points in empirical series.

We also used the following direction quality measure (see. e.g. Welfe and Brzeszczynski 2000):

$$
T P 2=\frac{N\left(r_{t} r_{t}^{*}>0\right)}{N\left(r_{t} r_{t}^{*} \neq 0\right)}
$$

where:

$N\left(r_{t} r_{t}^{*}>0\right)-$ a number of points in which direction changes in empirical and forecasting series are the same.

The most accurate forecasts we obtained from the equation with American indexes. Forecasts based on European indexes, however, were close to each other as far as errors are concerned. 
In the next Section we apply a methodology of combined forecasting. We test for relative importance of foreign stock markets in explaining WIG index.

\section{Combined forecasts of WIG index}

In order to assess the power of influence of foreign markets on Polish market we estimated the following Fair and Shiller (1990) equation (see e.g. Wdowinski 2004):

$$
y_{t}-y_{t-1}=\alpha_{0}+\alpha_{1}\left({ }_{t-1} \hat{y}_{1 t}-y_{t-1}\right)+\alpha_{2}\left({ }_{t-1} \hat{y}_{2 t}-y_{t-1}\right)+\varepsilon_{t} \text {, }
$$

where ${ }_{t-1} \hat{y}_{1 t}$ denotes one-period-ahead forecasts of $y_{t}$ generated by the model 1 , i.e. the model with American indexes based on information available up to the moment $t-1$ with the use of recursive estimation for each period $t$. The predictor ${ }_{t-1} \hat{y}_{2 t}$ denotes one-period-ahead forecasts generated accordingly by the model 2, i.e. the model with European indexes, while $\varepsilon$ is an error term, $\varepsilon \sim \operatorname{IN}\left(0, \sigma_{\varepsilon}^{2}\right)$. If neither model 1 , nor model 2 contain any relevant information in terms of forecasts quality for variable $y$ in period $t$, the estimates of $\alpha_{1}$ and $\alpha_{2}$ will be statistically insignificant. If both models generate forecasts that contain independent information, the estimates of $\alpha_{1}$ and $\alpha_{2}$ should both be statistically significant. If both models contain information but information contained in forecasts generated by model 2 is completely contained in forecasts generated by model 1 and furthermore model 1 contains additional relevant information, the estimate of $\alpha_{1}$ will be statistically significant while the estimate of $\alpha_{2}$ statistically insignificant. If both forecasts contain the same information, they are perfectly correlated and the estimation of parameters of (9) is not possible.

Because the influence of European markets was described by two equations, we estimated model (9) for two cases:

- $\quad$ for empirical WIG index and forecasts generated by (4) and (5).

- $\quad$ for empirical WIG index and forecasts generated by (4) and (6).

Below in Table 2 we present estimation results of equation (9).

Table 2. Estimation results of Fair and Shiller equation

\begin{tabular}{|c|c|c|c|c|c|c|c|c|c|c|c|c|}
\hline Intercept & DJIA-NASDAQ & DAX & FTSE & $\mathrm{S}_{\mathrm{e}}$ & $\mathrm{JB}$ & DW & $\mathrm{ARCH}$ & WHITE & Wald (USA) & Wald(EUR) & $\mathrm{R}^{2}$ (adj.) & obs. \\
\hline 0.0007 & 0.5495 & 0.3989 & $\bar{x}$ & 00119 & 0.6407 & 20719 & 0.2211 & 0.3888 & 4.4313 & 2.227 & 04429 & 250 \\
\hline 1.0018 & 2.105 & 1.4923 & $x$ & 0.0119 & (0.7258) & & $(0.6382)$ & $(0.4214)$ & $(0.0353)$ & (0.1356) & & \\
\hline $\begin{array}{l}0.0007 \\
1.0226\end{array}$ & $\begin{array}{l}0.6523 \\
3.1112\end{array}$ & $\begin{array}{l}x \\
x\end{array}$ & $\begin{array}{l}0.2915 \\
1.3777\end{array}$ & 0.0119 & $\begin{array}{c}0.8254 \\
(0.6618)\end{array}$ & 2.0818 & $\begin{array}{c}0.3223 \\
(0.5702)\end{array}$ & $\begin{array}{c}4.073 \\
(0.3961)\end{array}$ & $\begin{array}{c}9.6799 \\
(0.0019)\end{array}$ & $\begin{array}{c}1.8982 \\
(0.1683)\end{array}$ & 0.4422 & 250 \\
\hline
\end{tabular}

Source: own calculations. 
With italics we have denoted t-statistics with regard to estimates. Respective test probabilities with regard to test statistics are given in brackets. We applied the following tests: Jarque-Bera normality of residuals test (JB), conditional heteroscedasticity test (ARCH), White's test for heteroscedasticity (White), Wald coefficient restrictions test (Wald). The DW stands for Durbin-Watson test statistic.

The test statistics and their probabilities in case of JB, DW, ARCH and White's tests denote that errors in both models are normal, with no autocorrelation, no ARCH effects and no heteroscedasticity. Thus we can test the power of influence of foreign indexes on WIG index using t-statistic.

It can be easily seen that the influence of American market indexes DJIA and NASDAQ turned out to be more relevant for WIG index than European indexes DAX and FTSE. It is supported by the significance of estimates and their size. We can conclude, that information contained in forecasts generated by models (5) or (6) is fully contained in forecasts by model (4). Therefore, American indexes DJIA and NASDAQ were more influential than European indexes (DAX or FTSE) as regards WIG index. This conclusion is also confirmed by Wald coefficient restrictions test, i.e. we should reject the null that the respective coefficient equals zero in case of model (4) and should not reject the null in case of models (5) or (6).

Similar conclusions about the co-dependence of markets in case of Poland were drawn by e.g. Fiszeder (2003).

Since the parameters in equation (9) do not sum up to one, we should not treat them as weights in calculating combined forecasts.

Therefore, to calculate the weights, we used the nonlinear programming problem (NLP):

$$
\begin{aligned}
& \min f(\boldsymbol{\omega})=\boldsymbol{\omega}^{T} \mathbf{V} \boldsymbol{\omega}, \\
& \boldsymbol{\omega}^{T} \mathbf{1}=1, \\
& \boldsymbol{\omega} \geq \mathbf{0},
\end{aligned}
$$


where: $\boldsymbol{\omega}=\left[\begin{array}{l}\omega_{1} \\ \omega_{2}\end{array}\right]$ - is the vector of weights and $\mathbf{V}$ - the variance-covariance matrix of forecast errors.

In Table 3 we present covariances and correlations of forecasts errors.

Table 3. Covariance and correlation coefficients matrix of forecast errors

\begin{tabular}{cccc}
\multicolumn{5}{c}{ Covariance } \\
\hline DJIA-NASDAQ & DAX & FTSE \\
\hline DJIA-NASDAQ & 0.0001417 \\
DAX & 0.0001380 & 0.0001427 & \\
FTSE & 0.0001375 & 0.0001427 & 0.0001427 \\
\hline \multicolumn{4}{c}{ Correlation } \\
\hline DJIA-NASDAQ & DAX & FTSE \\
\hline DJIA-NASDAQ & 1 & & \\
DAX & 0.9708 & 1 & 1 \\
FTSE & 0.9546 & 0.9875 & 1 \\
\hline
\end{tabular}

Source: own calculations.

After solving the problem of nonlinear programming (10) we obtained the following weights which are given in Table 4.

Table 4. The weights in a NLP problem

\begin{tabular}{|c|c|c|}
\hline DJIA-NASDAQ & DAX & FTSE \\
\hline 0.5664 & 0.4336 & $\mathrm{X}$ \\
\hline 0.6734 & $\mathrm{X}$ & 0.3266 \\
\hline
\end{tabular}

Source: own calculations.

As we can notice the weights are close to estimated parameters in equation (9). Thus we confirmed earlier conclusions about the strong influence of American market on Polish stock market. As shown in Table 5, we could not substantially reduce the variance of combined forecast errors, because of the high and positive correlation between forecast errors from individual models (4), (5) and (6). 
Table 5. Variance of forecast errors

\begin{tabular}{|cc|}
\hline \multicolumn{2}{|c|}{ Individual forecast } \\
\hline DJIA-NASDAQ & 0.0001417 \\
DAX & 0.0001427 \\
FTSE & 0.0001427 \\
\hline \multicolumn{2}{|c|}{ Combined forecast } \\
\hline DJIA-NASDAQ-DAX & 0.0001406 \\
DJIA-NASDAQ-FTSE & 0.0001409 \\
\hline
\end{tabular}

Source: own calculations.

After calculating optimal weights, we calculated combined forecasts and assessed their accuracy. The results are given in Table 6 .

Table 6. Ex post errors of combined forecasts of WIG index

\begin{tabular}{|c|c|c|}
\hline & DJIA-NASDAQ-DAX & DJIA-NASDAQ-FTSE \\
\hline MAE & 0.00918 & 0.00916 \\
\hline RMSE & 0.01186 & 0.01188 \\
\hline THEIL & 0.78937 & 0.79123 \\
\hline $\mathrm{I}_{1}{ }^{2}$ & 0.005 & 0.005 \\
\hline $\mathrm{I}_{2}{ }^{2}$ & 0.514 & 0.515 \\
\hline $\mathrm{I}_{3}{ }^{2}$ & 0.537 & 0.534 \\
\hline TP 1 (\%) & 15 & 17 \\
\hline TP 2 $(\%)$ & 48.55 & 48.96 \\
\hline
\end{tabular}

Source: own calculations.

It is clearly shown that combined forecasts are not superior to forecasts obtained from each model separately.

Finally, we tested the forecasting quality of the equations including indexes of both foreign markets at the same time. We estimated the following equations:

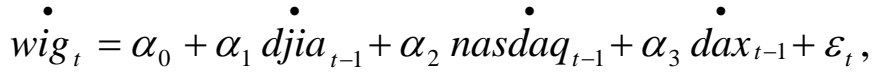

$$
\begin{aligned}
& \dot{w i g}_{t}=\beta_{0}+\beta_{1} \dot{d j i a}_{t-1}+\beta_{2} \text { nasdaq }_{t-1}+\beta_{3} \dot{f t s e}_{t-1}+\xi_{t} .
\end{aligned}
$$

The estimates of $\alpha_{3}$ and $\beta_{3}$ describing the influence of European market were usually insignificant. Also, as before, we obtained opposite signs of estimates which do not comply with the postulate of positive influence of the biggest stock markets on WIG index.

By applying the all-index approach itself we were not able to determine the power of influence of individual markets on the Polish market due to high correlation coefficients 
between indexes and difficulties in estimating the parameters. Therefore, the combined forecasts approach suggested in the paper can be considered correct.

Despite questionable statistics in results of regressions (11) and (12) and their weak economic properties we used them to forecast WIG index. The errors of these forecasts are shown in Table 7.

Table 7. Ex post errors of forecasts obtained in all-index equations

\begin{tabular}{|c|c|c|}
\hline & DJIA-NASDAQ-DAX & DJIA-NASDAQ-FTSE \\
\hline MAE & 0.00918 & 0.00932 \\
\hline RMSE & 0.01191 & 0.0123 \\
\hline THEIL & 0.75361 & 0.7531 \\
\hline$I_{1}{ }^{2}$ & 0.005 & 0.005 \\
\hline $\mathrm{I}_{2}{ }^{2}$ & 0.42 & 0.394 \\
\hline $\mathrm{I}_{3}{ }^{2}$ & 0.579 & 0.606 \\
\hline $\mathrm{TP} 1(\%)$ & 21.26 & 19.69 \\
\hline $\mathrm{TP} 2(\%)$ & 51.04 & 50.21 \\
\hline
\end{tabular}

Source: own calculations.

As in the case of combined forecasts they are not of better quality than forecasts obtained from individual models separately.

\section{Conclusions}

In this paper we attempted to assess the influence of American and European stock markets on Polish stock market. In our analysis we used the GARCH methodology which is popular to describe the financial phenomena of high frequency. We have found that the situation on American market had more influence on Polish market than the situation on European markets in the analysed period during 1.01.1995 - 29.12.2003. We based these conclusions on the analysis of forecasting equations for WIG index and on the analysis of combined forecasting. Our results are consistent with those obtained by other authors for the Polish stock market (see e.g. Fiszeder 2001 and 2003; Brzeszczynski and Kelm 2002).

We should notice, however, a few aspects which can affect conclusions drawn from this kind of research.

Firstly, it must be remembered that there is a strong co-dependence among the biggest stock markets so it is difficult to show the impact of one individual market on another one in a simple approach. 
Secondly, it is very important to choose the proper indexes as determinants of market development. It is necessary, then, to test also the influence of other indexes and stock markets - including emerging markets - on Polish market.

Thirdly, Polish stock market may be treated by foreign investors as one of secondary importance, and consequently domestic investment funds may influence the variability of returns more than situation on foreign markets.

In the paper we have used only series of 250 one-period-ahead forecasts. In future research we will attempt to show how the parameters reflecting the influence of American stock market and other markets on Polish market change over time.

\section{Literature}

Agmon T. (1972), The Relations Among Equity Markets in the United States, United Kingdom and Japan, Journal of Finance, 28, 839-855.

Akgiray V. (1989), Conditional heteroskedasticity in time series of stock returns: evidence and forecasts, Journal of Business, 62, 55-80.

Andersen T.G., Bollerslev T., Lange S. (1999), Forecasting financial market volatility: Sample frequency vis-avis forecast horizon, Journal of Empirical Finance, 6, 457-477.

Baillie R.T., Bollerslev T., Mikkelsen H.O. (1996), Fractionally integrated generalized autoregressive conditional heteroskedasticity, Journal of Econometrics, 74, 3-30.

Billio M., Sartore D., Toffano C. (2000), Combining forecasts: some results on exchange and interest rates, The European Journal of Finance, 6, 126-145.

Bollerslev T. (1986), Generalized Autoregressive Conditional Heteroskedasticity, Journal of Econometrics, 31, 307-327.

Bollerslev T., Wright J.H. (2000), Semiparametric estimation of long-memory volatility dependencies: The role of high-frequency data, Journal of Econometrics, 98, 81-106.

Bracker K., Koch P.D. (1999), Economic Determinants of the Correlation Structure Across International Equity Markets, Journal of Economics and Business, 51, 443-471.

Brzeszczynski J., Kelm R. (2002), Econometric Models of Financial Markets. Models of Stock Prices and Exchange Rates, WIG-Press, Warszawa.

Claessen H., Mittnik S. (2002), Forecasting stock market volatility and the informational efficiency of the DAXindex options market, The European Journal of Finance, 8, 302-321.

Clemen R.T. (1989), Combining forecasts: a review and annotated bibliography, International Journal of Forecasting, 5, 559-83.

Clemen R.T., Winkler R.L. (1986), Combining economic forecasts, Journal of Business and Economic Statistics, 4, 39-46.

Ding Z., Granger C.W.J., Engle R.F. (1993), A Long Memory Property of Stock Market Returns and a New Model, Journal of Econometrics, 73, 185-215.

Doman M., Doman R. (2003), Forecasting Daily Volatility of WIG Index with Higher Frequency Data, [in:] 
Milo W., Wdowinski P. (eds.) New Methods of Analysis and Forecasting Financial Markets, Zeszyt Naukowy No. 166, Lodz University Press, Lodz (in Polish).

Engle R., Kroner K. (1995), Multivariate simultaneous GARCH, Econometric Theory, 11, 122-150.

Engle R.F. (1982), Autoregressive Conditional Heteroscedasticity with Estimates of the Variance of the United Kingdom Inflation, Econometrica, 50, 987-1008.

Engle R.F., Bollerslev T. (1986), Modeling the Persistence of Conditional Variance, Econometric Reviews, 5, 150.

Engle R.F., Lilien D. M., Robins R. P. (1987), Estimating Time Varying Risk Premia in the Term Structure: The ARCH-M Model, Econometrica, 55, 391-407.

Engle R.F., Susmel R. (1993), Common Volatility in International Equity Markets, Journal of Business \& Economic Statistics, 11, 167-176.

Erb C.B., Harvey C.R., Viskanta T.E. (1994), Forecasting International Equity Correlations, Financial Analyst Journal, Nov.-Dec., 32-45.

Fair R.C., Shiller R.J. (1990), Comparing information in forecasts from econometric models, The American Economic Review, Vol. 80, No. 3, June, pp. 375-89.

Fiszeder P. (2001), GARCH Modelling of Short-term Co-dependence Between the Warsaw Stock Exchange and International Stock Markets, Przeglad Statystyczny, 48, 345-363 (in Polish).

Fiszeder P. (2003), Stability Tests of Correlation Coefficients in Multivariate GARCH Model - An Analysis of Correlation Between Stock Indexes: WIG, DJIA and NASDAQ COMPOSITE, Przeglad Statystyczny, 50, 345-363 (in Polish).

Glosten L.R., Jagannathan R., Runkle D.E. (1993), On the Relation Between the Expected Value and Volatility of the Nominal Excess Return on Stocks, Journal of Finance, 48, 1779-1801.

Granger C.W.J. (1989), Invited review: combining forecasts - 20 years later, Journal of Forecasting, 8, 167-173.

Grubel H. (1968), Internationally Diversified Portfolios: Welfare Gains and Capital Flows, American Economic Review, 58, 1299-1314.

Hamao Y., Masulis R.W., Ng V. (1990), Correlations in Price Changes and Volatility Across International Stock Markets, The Review of Financial Studies, 3, 281-307.

King M.A., Wadhwani S. (1990), Transmission of Volatility Between Stock Markets, The Review of Financial Studies, 3, 5-33.

Levy J., Sarnat M. (1970), International Diversification of Investment Portfolios, American Economic Review, 60, 668-675.

Nelson D. (1991), Conditional Heteroscedasticity in Asset Returns: A New Approach, Econometrica, 59, 347370.

Osiewalski J, Pipien M. (1999), Estimation of GARCH Models: ML and Bayesian Methods, Przeglad Statystyczny 46, z2 (in Polish).

Osiewalski J., Pipien M. (2004), Bayesian Comparison of Bivariate ARCH-Type Models for the Main Exchange Rates in Poland, Journal of Econometrics 123 (2), 371-391.

Schwert G.W., Seguin P.J. (1990), Heteroskedasticity in stock returns, Journal of Finance, 13, 838-851.

Taylor S.J. (1986), Modeling Financial Time Series, Wiley, Chichester.

Wdowinski P. (2004), Determinants of Country Beta Risk in Poland, CESifo Working Paper No. 1120. 
Welfe A., Brzeszczynski J. (2000), Direction Quality Measures for ARCH Models: The Case of Warsaw Stock Exchange Stock Prices, [in:] Welfe W., Wdowinski P. (eds.), Macromodels '99, Conference Proceedings, Absolwent, Lodz. 


\title{
CESifo Working Paper Series
}

\author{
(for full list see www.cesifo-group.de)
}

1509 Jean Hindriks and Ben Lockwood, Decentralization and Electoral Accountability: Incentives, Separation, and Voter Welfare, July 2005

1510 Michelle R. Garfinkel, Stergios Skaperdas and Constantinos Syropoulos, Globalization and Domestic Conflict, July 2005

1511 Jesús Crespo-Cuaresma, Balázs Égert and Ronald MacDonald, Non-Linear Exchange Rate Dynamics in Target Zones: A Bumpy Road towards a Honeymoon - Some Evidence from the ERM, ERM2 and Selected New EU Member States, July 2005

1512 David S. Evans and Michael Salinger, Curing Sinus Headaches and Tying Law: An Empirical Analysis of Bundling Decongestants and Pain Relievers, August 2005

1513 Christian Keuschnigg and Martin D. Dietz, A Growth Oriented Dual Income Tax, July 2005

1514 Fahad Khalil, David Martimort and Bruno Parigi, Monitoring a Common Agent: Implications for Financial Contracting, August 2005

1515 Volker Grossmann and Panu Poutvaara, Pareto-Improving Bequest Taxation, August 2005

1516 Lars P. Feld and Emmanuelle Reulier, Strategic Tax Competition in Switzerland: Evidence from a Panel of the Swiss Cantons, August 2005

1517 Kira Boerner and Silke Uebelmesser, Migration and the Welfare State: The Economic Power of the Non-Voter?, August 2005

1518 Gabriela Schütz, Heinrich W. Ursprung and Ludger Wößmann, Education Policy and Equality of Opportunity, August 2005

1519 David S. Evans and Michael A. Salinger, Curing Sinus Headaches and Tying Law: An Empirical Analysis of Bundling Decongestants and Pain Relievers, August 2005

1520 Michel Beine, Paul De Grauwe and Marianna Grimaldi, The Impact of FX Central Bank Intervention in a Noise Trading Framework, August 2005

1521 Volker Meier and Matthias Wrede, Pension, Fertility, and Education, August 2005

1522 Saku Aura and Thomas Davidoff, Optimal Commodity Taxation when Land and Structures must be Taxed at the Same Rate, August 2005

1523 Andreas Haufler and Søren Bo Nielsen, Merger Policy to Promote 'Global Players’? A Simple Model, August 2005 
1524 Frederick van der Ploeg, The Making of Cultural Policy: A European Perspective, August 2005

1525 Alexander Kemnitz, Can Immigrant Employment Alleviate the Demographic Burden? The Role of Union Centralization, August 2005

1526 Baoline Chen and Peter A. Zadrozny, Estimated U.S. Manufacturing Production Capital and Technology Based on an Estimated Dynamic Economic Model, August 2005

1527 Marcel Gérard, Multijurisdictional Firms and Governments' Strategies under Alternative Tax Designs, August 2005

1528 Joerg Breitscheidel and Hans Gersbach, Self-Financing Environmental Mechanisms, August 2005

1529 Giorgio Fazio, Ronald MacDonald and Jacques Mélitz, Trade Costs, Trade Balances and Current Accounts: An Application of Gravity to Multilateral Trade, August 2005

1530 Thomas Christiaans, Thomas Eichner and Ruediger Pethig, A Micro-Level 'Consumer Approach’ to Species Population Dynamics, August 2005

1531 Samuel Hanson, M. Hashem Pesaran and Til Schuermann, Firm Heterogeneity and Credit Risk Diversification, August 2005

1532 Mark Mink and Jakob de Haan, Has the Stability and Growth Pact Impeded Political Budget Cycles in the European Union?, September 2005

1533 Roberta Colavecchio, Declan Curran and Michael Funke, Drifting Together or Falling Apart? The Empirics of Regional Economic Growth in Post-Unification Germany, September 2005

1534 Kai A. Konrad and Stergios Skaperdas, Succession Rules and Leadership Rents, September 2005

1535 Robert Dur and Amihai Glazer, The Desire for Impact, September 2005

1536 Wolfgang Buchholz and Wolfgang Peters, Justifying the Lindahl Solution as an Outcome of Fair Cooperation, September 2005

1537 Pieter A. Gautier, Coen N. Teulings and Aico van Vuuren, On-the-Job Search and Sorting, September 2005

1538 Leif Danziger, Output Effects of Inflation with Fixed Price- and Quantity-Adjustment Costs, September 2005

1539 Gerhard Glomm, Juergen Jung, Changmin Lee and Chung Tran, Public Pensions and Capital Accumulation: The Case of Brazil, September 2005

1540 Yvonne Adema, Lex Meijdam and Harrie A. A. Verbon, The International Spillover Effects of Pension Reform, September 2005 
1541 Richard Disney, Household Saving Rates and the Design of Social Security Programmes: Evidence from a Country Panel, September 2005

1542 David Dorn and Alfonso Sousa-Poza, Early Retirement: Free Choice or Forced Decision?, September 2005

1543 Clara Graziano and Annalisa Luporini, Ownership Concentration, Monitoring and Optimal Board Structure, September 2005

1544 Panu Poutvaara, Social Security Incentives, Human Capital Investment and Mobility of Labor, September 2005

1545 Kjell Erik Lommerud, Frode Meland and Odd Rune Straume, Can Deunionization Lead to International Outsourcing?, September 2005

1546 Robert Inklaar, Richard Jong-A-Pin and Jakob de Haan, Trade and Business Cycle Synchronization in OECD Countries: A Re-examination, September 2005

1547 Randall K. Filer and Marjorie Honig, Endogenous Pensions and Retirement Behavior, September 2005

1548 M. Hashem Pesaran, Til Schuermann and Bjoern-Jakob Treutler, Global Business Cycles and Credit Risk, September 2005

1549 Ruediger Pethig, Nonlinear Production, Abatement, Pollution and Materials Balance Reconsidered, September 2005

1550 Antonis Adam and Thomas Moutos, Turkish Delight for Some, Cold Turkey for Others?: The Effects of the EU-Turkey Customs Union, September 2005

1551 Peter Birch Sørensen, Dual Income Taxation: Why and how?, September 2005

1552 Kurt R. Brekke, Robert Nuscheler and Odd Rune Straume, Gatekeeping in Health Care, September 2005

1553 Maarten Bosker, Steven Brakman, Harry Garretsen and Marc Schramm, Looking for Multiple Equilibria when Geography Matters: German City Growth and the WWII Shock, September 2005

1554 Paul W. J. de Bijl, Structural Separation and Access in Telecommunications Markets, September 2005

1555 Ueli Grob and Stefan C. Wolter, Demographic Change and Public Education Spending: A Conflict between Young and Old?, October 2005

1556 Alberto Alesina and Guido Tabellini, Why is Fiscal Policy often Procyclical?, October 2005

1557 Piotr Wdowinski, Financial Markets and Economic Growth in Poland: Simulations with an Econometric Model, October 2005 
1558 Peter Egger, Mario Larch, Michael Pfaffermayr and Janette Walde, Small Sample Properties of Maximum Likelihood Versus Generalized Method of Moments Based Tests for Spatially Autocorrelated Errors, October 2005

1559 Marie-Laure Breuillé and Robert J. Gary-Bobo, Sharing Budgetary Austerity under Free Mobility and Asymmetric Information: An Optimal Regulation Approach to Fiscal Federalism, October 2005

1560 Robert Dur and Amihai Glazer, Subsidizing Enjoyable Education, October 2005

1561 Carlo Altavilla and Paul De Grauwe, Non-Linearities in the Relation between the Exchange Rate and its Fundamentals, October 2005

1562 Josef Falkinger and Volker Grossmann, Distribution of Natural Resources, Entrepreneurship, and Economic Development: Growth Dynamics with Two Elites, October 2005

$1563 \mathrm{Yu}-\mathrm{Fu}$ Chen and Michael Funke, Product Market Competition, Investment and Employment-Abundant versus Job-Poor Growth: A Real Options Perspective, October 2005

1564 Kai A. Konrad and Dan Kovenock, Equilibrium and Efficiency in the Tug-of-War, October 2005

1565 Joerg Breitung and M. Hashem Pesaran, Unit Roots and Cointegration in Panels, October 2005

1566 Steven Brakman, Harry Garretsen and Marc Schramm, Putting New Economic Geography to the Test: Free-ness of Trade and Agglomeration in the EU Regions, October 2005

1567 Robert Haveman, Karen Holden, Barbara Wolfe and Andrei Romanov, Assessing the Maintenance of Savings Sufficiency Over the First Decade of Retirement, October 2005

1568 Hans Fehr and Christian Habermann, Risk Sharing and Efficiency Implications of Progressive Pension Arrangements, October 2005

1569 Jovan Žamac, Pension Design when Fertility Fluctuates: The Role of Capital Mobility and Education Financing, October 2005

1570 Piotr Wdowinski and Aneta Zglinska-Pietrzak, The Warsaw Stock Exchange Index WIG: Modelling and Forecasting, October 2005 